Acta Poloniae Historica

116, 2017

PL ISSN 0001-6829

\title{
Kristina Friedrichs
}

Institute of Art History

Julius-Maximilians-Universtät Würzburg

\section{COURT CHAPELS IN SAXONY BETWEEN 1697 AND 1733: AUGUSTUS II THE STRONG BETWEEN CATHOLICISM AND PROTESTANTISM}

\begin{abstract}
When Augustus II the Strong (1670-1733) converted from the Protestant to the Catholic confession, he guaranteed his subjects - all Lutheran - the free exercise of their religion and belief. He also respected their wish not to allow the 'new' old confession emerge too overtly in the motherland of Martin Luther and the Reformation. Consequently, the Catholic chapels he built during his reign in Saxony were constructed in private in order to assure the peaceful co-existence of the confessions. What may appear to be a tolerant religious policy was in fact almost the contrary: This article will briefly illuminate the historical and political background of Augustus' decisions, while the main focus will be to examine the newly installed Catholic court chapels.
\end{abstract}

Keywords: Catholicism, Protestantism, Augustus II the Strong, Saxony, court chapels, art history

\section{I \\ INTRODUCTION}

The conversion of Augustus II the Strong in 1697 had far reaching consequences on the religious and political landscape of Central and Eastern Europe. Augustus soon found himself caught between two parties of interest: the Catholic Church and their expectations and his strictly Protestant population. He had to satisfy each party without offending them. Thus, the homogeneous confessional setting of Saxony changed, allowing for the possibility of religious diversification. ${ }^{1}$

${ }^{1}$ Abbreviations in this article: HStA - Hauptstaatsarchiv Dresden; LfD - Landesamt für Denkmalpflege Dresden; SLUB - Sächsische Landesbibliothek - Staats- und Universitätsbibliothek Dresden. 
The elector's conversion created a need for places of Catholic worship, but since the Peace of Westphalia Catholics in Saxony were only allowed to celebrate the mess in private houses. At this point it is worth looking at court chapels that were established under Augustus' rule, either by re-consecrating already existing buildings or by designing new chapels. Examining how the freshly introduced Catholicism dealt with the traditional Protestant language of architecture and religious iconography may help to understand the contact between the two confessions in this special situation.

In order to approach this problem, the article will begin with a brief analysis of the political background. Next, the architecture and iconography of some of the court chapels built during the reign of Augustus will be described and compared with Protestant structures. The chapels chosen are as follows: first, the court chapel at the Moritzburg Castle (Schloss Moritzburg), which was the first to be consecrated as a Catholic chapel; second, the court chapel at the main residence Dresden Castle (Dresdner Residenzschloss), which was established before a real Catholic church was built in the city; the third to be examined is the chapel at the Pleissenburg (Pleißenburg), close to Leipzig, which was an important centre of trade in Central Eastern Europe; fourth, the chapel at Pillnitz Castle (Schloss Pillnitz), a building of minor political importance; and the fifth and final part of this study will deal with a chapel in a not completely realized palace, the Japanese Palace (Japanisches Palais), which was intended to be the main place of Augustus' stately representation in Saxony. By examining these chapels, it will become clear in which instances the court had to be explicit about the chosen confession of a chapel and where it was appropriate to keep with Protestant ideals.

Questions that can be asked in this context mainly concern the design decisions and their religious implications: What were the main characteristics of Augustan religious architecture? To what extent could typical Catholic imagery and building structures be utilized? How can they be compared to Protestant buildings? Thus, a picture of the coexistence of Protestantism and Catholicism can be drawn from the perspective of art history. 
II

\section{POLITICAL BACKGROUND}

Augustus II the Strong, born in 1670, was the elector of Saxony, imperial vicar and very much interested in the expansion of his power. It was primarily his physical strength that led to his alias 'the Strong', although his vigorous will to use diverse political strategies to enhance his standing was also well portrayed by this nickname.

Saxony was the motherland of Protestantism, and its confessional uniformity had even become a kind of religious symbol. Furthermore, the ruler of Saxony belonged to the electors of the German emperor, a small and very elite group of nine princes. Saxony and the Palatinate of the Rhine substituted the emperor sede vacante, ${ }^{2}$ a privilege that for Augustus played an important role in his personal vita: he exercised the vicariate after the death of Joseph I from 18 April to 12 October 1711. He was also the principal protector of the Corpus Evangelicorum, the league of Protestant states within the Empire. But this degree of power was not enough - Augustus aimed for more: more power, more independence from the Empire and more land to reign over. ${ }^{3}$

Thus, when the possibility emerged to be elected head of the great Kingdom of Poland, Augustus concentrated all of his efforts to achieve his promotion amongst the crowned heads, just like his rival Brandenburg aimed to obtain the kingship through the Prussian crown. One premise was the conversion to Catholic faith, ${ }^{4}$ as decided by the Polish Parliament in 1669. This was indeed a serious step to take, as it affected the whole political and religious landscape of Central and Eastern Europe. ${ }^{5}$ Although the dividing lines between Catholicism

2 The realms of the two vicars were determined by the differentiation in countries belonging to the Saxon law and those belonging to Franconian law.

${ }^{3}$ Johannes Ziekursch, 'August der Starke und die katholische Kirche in den Jahren 1697 bis 1720', Zeitschrift für Kirchengeschichte, xxiv (1903), 86-135 and 232-80, here: 91 .

${ }^{4}$ Jacek Staszewski, 'Begründung und Fortsetzung der Personalunion SachsenPolen 1697 und 1733', in Rex Rexheuser (ed.), Die Personalunionen von Sachsen-Polen 1697-1763 und Hannover-England 1714-1837 (Wiesbaden, 2005), 37-50.

${ }^{5}$ In Poland the reign of Augustus marked a clear divergence from the mainly tolerant atmosphere, as the example of the tumult of Thorn shows - although this event coincided with a general tendency of mutual distrust among the various confessions. Janusz Tazbir, Geschichte der polnischen Toleranz (Warszawa, 1977), 179. 
and Protestantism were firmly drawn within the Empire, conversions were not exceptional. For example, Christian August of Saxony-Zeitz (1666-1725) converted to Catholicism in 1689 and made a career in the Catholic Church as bishop of Győr and later as cardinal. ${ }^{6}$ Also, Anton Ulrich of Braunschweig-Wolfenbüttel converted secretly to the Catholic faith in 1709, assuring his people their right to the Protestant faith after having made his personal decision public. ${ }^{7}$ Karl Alexander of Württemberg (1684-1737) converted to Catholicism in 1712 after having obtained a career in the Emperor's army. When his uncle Eberhard Ludwig died without a son, the regency over Württemberg shifted to him.

It appears that most of those who converted to Catholicism were neither particularly concerned about the consequences nor did they have strong feelings towards religion, so that the impact of their conversion was not always thought through in advance. ${ }^{8}$ The conversion to Catholicism brought several advantages for Augustus besides his qualification for the office as Polish king. First of all, his connection to the most powerful rulers, the Pope and the Catholic emperor of the German Nations, grew much closer. ${ }^{9}$ Furthermore, promising marriages with Catholic partners would be allowed, an opportunity that Augustus was also able to obtain for his son and successor. Generally speaking, the possibility of gaining a good livelihood due to Catholic offices was much higher than with Protestant offices, as shown in the case of Christian August, and the concept of an absolute ruler could be much stronger supported by Catholic ideals than by Protestant ideals. ${ }^{10}$

Thus, on 2 June 1697, Augustus committed himself to the Catholic faith in the court chapel of Baden, close to Vienna. He made his

${ }^{6}$ Siegfried Seifert, Niedergang und Wiederaufstieg der katholischen Kirche in Sachsen (Leipzig, 1964), 120-2.

${ }^{7}$ Günther Christ, 'Fürst, Dynastie, Territorium und Konfession', Saeculum, xxiv (1973), 367-87, here: 372; Jochen Vötsch, Kursachsen, das Reich und der mitteldeutsche Raum zu Beginn des 18. Jahrhunderts (Frankfurt, 2003), 281. This idea is supported by Karlheinz Blaschke, who also takes into account the exceptional personality of Augustus; idem, 'Sachsens Interessen und Ziele in der sächsisch-polnischen Personalunion', in Rexheuser (ed.), Personalunionen, 67-86.

${ }^{8}$ Christ, 'Fürst', 369.

${ }_{9}$ Vötsch, Kursachsen, 21.

10 Seifert, Niedergang und Wiederaufstieg, 123. 
profession of faith to his grand cousin, the above-mentioned Christian August. However, Augustus kept this step secret, until it had become clear that the way to the Polish crown was paved, ${ }^{11}$ a strategy which he even openly explained to the Papal court. ${ }^{12}$ During a later ceremony in Piekary on 27 July 1697, the conversion was made public. ${ }^{13}$

Finally, the opportunist Augustus became elected Polish king on 15 September 1697, though not without struggles and the payment of an enormous amount of funds. ${ }^{14}$ Since 1704 , he attempted to marry his son to the Archduchess of Austria, the oldest daughter of Joseph I of Habsburg. But the Pope expected signs of true religious devotion, and thus required the conversion of August's wife and child, the promise to do missionary work in Saxony, and regular Catholic services in Leipzig and Dresden.

It was obvious before Augustus converted that major problems would be caused by his choice. His position in the Corpus Evangelicorum could only be exercised through a surrogate from another Saxon line, Saxony-Weißenfels, ${ }^{15}$ resulting in a functional shift from Saxony to Hannover and Brandenburg in the following decades. Augustus also had to withdraw from control over the Saxon Church for whom he had served as summus episcopus. From that time on, the Privy Council exercised control as an intermediate institution.

Augustus' wife, Christiane Eberhardine (1671-1727) of Brandenburg-Bayreuth, did not give up her Protestant faith and insisted on educating their son, Frederick Augustus II (1696-1763), according to Protestant ideals. This included that he should not be influenced towards a confessional change, which could turn the single case of his father into a permanent change of Saxony's ruling dynasty. But after he had been raised as a Protestant and even completed his

${ }^{11}$ Klaus Fitschen, 'Der Glaubenswechsel Augusts des Starken im Spannungsfeld toleranz- und konfessionspolitischer Probleme', in Frank-Lothar Kroll and Hendrik Thoß (eds.), Zwei Staaten, eine Krone. Die polnisch-sächsische Union 1697-1763 (Berlin, 2016), 165-74, here: 168 .

${ }^{12}$ Cited in Ziekursch, 'August der Starke', 98, n. 1.

${ }^{13}$ Paul Haake, 'Der Glaubenswechsel Augusts des Starken', Historische Vierteljahresschrift, x (1907), 382-92. For the complete citation of the ceremony cf. 390-1.

${ }^{14}$ Staszewski, 'Begründung und Fortsetzung', 42-5.

${ }^{15}$ Weißenfels was no actual substitute, but had to ask for allowance for all decisions from Dresden. Dagmar Freist, 'Religionssicherheiten und Gefahren für das "Seelenheil"', in Gerhard Poppe and Ulrich Rosseaux (eds.), Konfession und Konflikt (Münster, 2012), 35-53, here: 38; Vötsch, Kursachsen, 66-83. 
confirmation in 1710, the prince secretly converted to Catholicism in Bologna on 27 November 1712. Interestingly, in 1701 Augustus had already assured the Pope that his son would convert to Catholicism, and he used Jesuit priests to gain influence over the religious ideas of his son, as well as by sending him during his grand tour also to Italy. ${ }^{16}$ For the future marriage with the emperor's daughter and for the potential of retaining the Polish crown, ${ }^{17}$ Fredericks' conversion provided some promising opportunities. It was not until 11 October 1717 that Frederick Augustus' conversion was publicly announced, shortly after his marriage had been arranged. It was finally celebrated on 20 August 1719 in Vienna.

As previously mentioned, Augustus' decision was supposed to be a private one without further consequences for Protestant Saxony. However, given the political function of the elector, this idea seems ludicrous. ${ }^{18}$ The population of Saxony remained Protestant, and out of distrust, the Estates ${ }^{19}$ advocated vigorously for their faith. The latter were truly alarmed by the conversion and pushed for an edict securing their religion. Consequently, Augustus signed the decree of Łobzów in 1697 and further edicts in 1705 as well as in 1717. It was stated that Protestantism should remain the only confession in Saxony, that it had to be protected, and that no missionary work was allowed. One point especially relevant to our topic was the rule that Catholic worship could only be practiced in completely private settings, not even allowing services to be open to other Catholics.

In fact, Catholic worship had been practiced in Saxony exclusively in private settings, but nevertheless with other participating persons not belonging to the family of the owner of the house. This led to

${ }^{16}$ Christ, 'Fürst', 375; Seifert, Niedergang und Wiederaufstieg, 149-53.

17 As early as 1699 , but especially after 1714, the idea of the heritability of the Polish crown grew more important in the house of Wettin. Józef A. Gierowski, 'Personal- oder Realunion?', in Johannes Kalisch and Józef A. Gierowski, Um die polnische Krone (Berlin, 1962), 254-91, here: 270-4. See also Staszewski, 'Begründung und Fortsetzung', 46-7.

18 Since the Peace of Augsburg, the ius reformandi was applicable so that the population had - at least in theory - to follow a conversion of their ruler.

${ }^{19}$ Christ, 'Fürst', 384. See also Gierowski for the Polish as well as Saxon reactions towards the conversion and the political implications of Augustus' simultaneous office: Józef A. Gierowski, 'Die sächsisch-polnische Personalunion als Problem des Monarchen aus polnischer Sicht', in Rexheuser (ed.), Personalunionen, 121-52, esp. 136-8. 
several complaints from Protestants ${ }^{20}$ who interpreted this practice as public worship. ${ }^{21}$ In order to prevent such appeals, the edict pronounced that only members of the royal family and court could join the Catholic services.

No Catholic assembly room was allowed to be visible to the public, the worship had to remain in a closed setting. For the architecture this premise had a major impact: chapels could only be established without changing the existing structures or had to lie within a larger complex. Thus, the architectural designs needed to be kept to modest sizes and forms.

However, the Catholic Church - not only the Pope but also the emperor - expected Augustus to commit himself clearly to his new confession, to build at least places of worship for the Catholic community, which was expected to grow in the following years. Mere lip service from the king would have been completely disappointing for the forces that supported Augustus' political aims. Thus, he needed to take action to satisfy those expectations.

\section{III \\ MORITZBURG CASTLE}

It took two full years until the elector-king met those expectations and established a Catholic chapel in the summer residence and hunting lodge in Moritzburg. This establishment, in fact, was only a repurposing of the former Protestant chapel. The castle itself had been built after the year 1542 during the reign of elector Moritz, but the chapel in the southern wing was created in the seventeenth century. The builder Wolf Caspar of Klengel (1630-91) developed the design for the new baroque palace as well as for the attached court chapel. The construction began in 1661 and the chapel was consecrated on 24 June 1672.

${ }^{20}$ Many complaints also concerned marriages, the baptism of children of parents with different confessions, and the question of burials of Catholics as well as the pastoral care of prisoners.

${ }^{21}$ Freist, 'Religionssicherheiten', 44-5; Paul F. Saft, Der Neuaufbau der katholischen Kirche in Sachsen im 18. Jahrhundert (Leipzig, 1961), 50-70; Gerd Schwerhoff, 'Konfessionskonflikte um 1700 zwischen instrumenteller Religionspolitik und konfessioneller Mobilisierung', in Poppe and Rosseaux (eds.), Konfession und Konflikt, 17-34, here: 20 . 
Still today, the chapel is clearly visible from the outside as it is mounted by a ridge turret reaching the height of 22 meters. Inside, it was laid out as a hall, 17.2 metres long, 10.5 metres wide and 13.1 metres high. ${ }^{22}$ The chapel extends over two stories offering two access points to the hall: one on the floor level and one on the level of the boxes. On the western wall, a box for the service's singers was included, in front of which stood the altar. The main altar painting was created in 1669 by the Italian Stefano Cattaneo and displayed the transfiguration of Christ, based on passages from the Gospels (Lk 9, Mk 9 and Mt 17). It was surmounted by a small round image of the Holy Spirit painted by Johann Fink in 1670. The southern wall contained a pulpit whose iconography was quite simple with acanthus, angel heads and the dove as a symbol for the Holy Spirit. On the northern wall, the so-called Heerespaukerstand duplicated the pulpit, although its purpose was to house a drum used as a musical instrument. The eastern wall had several boxes for the spectators of the ceremony: two lower, curved boxes were reserved for members of the nobility, while one large box housed the royal family. Below that, an access for court members and villagers was integrated in the eastern wall. ${ }^{23}$ With its white colour, the stucco ornaments and the subtle gilding, the chapel was a simple but elegant place of worship (fig. 1).

Shortly after his conversion, still in the year 1697, Augustus decided to have the court chapel of Moritzburg repurposed for Catholic use. The Christmas ceremony of 1699, celebrated by the Jesuit father Carlo Maurizio Vota (1629-1715), marked the beginning of regular Catholic services in Saxony after the Reformation. Johann Paldamus was appointed as permanent priest of the chapel for future services. ${ }^{24}$

In the first years after this new dedication, no alterations were made to the existing structures. In 1703 Augustus personally produced some architectural drawings with the chapel itself unchanged, although the general concept of the palace was intended to be profoundly remodelled. ${ }^{25}$ It was not until 1723-8 that Matthäus Daniel Pöppelmann carried out several changes to the chapel. Those modifications

${ }^{22}$ Hans-Günther Hartmann, Moritzburg. Schloß und Umgebung in Geschichte und Gegenwart (Weimar, 1990), 34-9; Iris Kretschmann, Schlosskapelle Moritzburg (München, 1991), 5.

${ }^{23}$ Hartmann, Moritzburg, 41-3.

${ }^{24}$ For the celebration cf. ibidem, 121; Seifert, Niedergang und Wiederaufstieg, 141.

${ }^{25}$ Hartmann, Moritzburg, 57. 


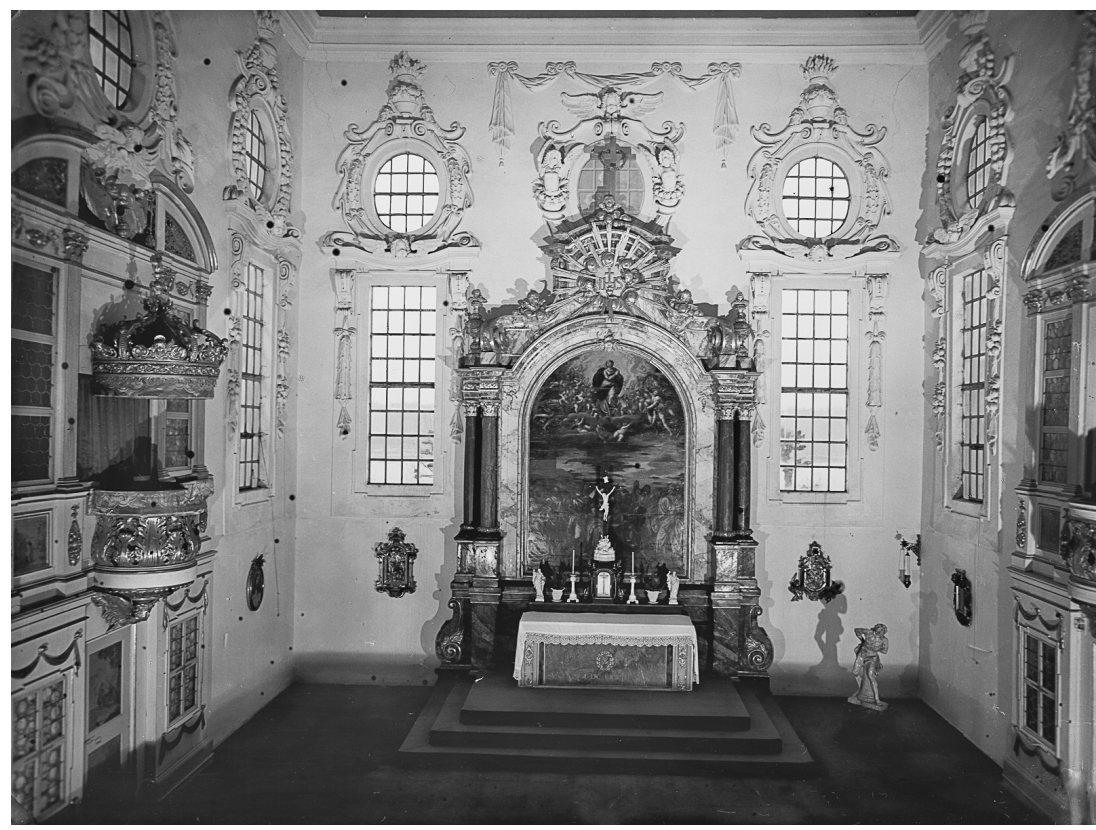

Fig. 1. Interior of the court chapel in Moritzburg, photo Hans Wunderlich, 1933, SLUB/Deutsche Fotothek.

mainly concerned the connection of the chapel with the palace: a new gallery was introduced, so that the king's box became bigger and more easily accessible from the palace's rooms. Another gallery just below the ceiling completed the picture.

As required by the Catholic rite, relics were deposited in the altar, but this step was not undertaken until $1721 .{ }^{26}$ Paintings originating from the Protestant building period were also substituted much later: they remained until 1746 when the altar retable was replaced by the ascension of Mary - a non-biblical story - most probably chosen by the Jesuits at Dresden's court. ${ }^{27}$ Interestingly, prior to 1733 there were no pictures of the Virgin Mary used in Dresden, not even in the Jesuit's own sphere. ${ }^{28}$

${ }^{26}$ Kretschmann, Schlosskapelle, 2.

27 Ibidem, 11. The picture was initially bought in Italy for the king's collection of paintings, but soon after its arrival in Dresden it was transferred to Moritzburg.

${ }^{28}$ Esther Meier, Sakralkunst am Hof zu Dresden. Kontext als Prozess (Berlin, 2015), 68. 
Due to the damages caused by a fire, it was only after the death of Augustus that more extensive modifications were introduced to the chapel: The gallery for the musicians and singers had to be demolished, as the altar was transferred to the western end of the sanctuary. Many pieces of the altar, such as the columns and the marble plate, were reused, although the altar as a whole became much larger than before and a gloriole with angels was added. ${ }^{29}$

The painting on the ceiling, created in 1670 by Johann Fink that displays the ascension of Christ, was not altered during the time of Augustus, who only slightly restored it, nor was it altered during his son's reign. This iconography was perfectly acceptable for both confessions. ${ }^{30}$ It points to the commonly accepted concept that even the reign of an elector is given by God and he has to take responsibility for his actions in front of the Lord.

This is a typical characteristic of Protestant courtly art even during absolutism and can be found in various examples. ${ }^{31}$ Also the dedicational inscription that mentioned the founder of the chapel, Johann Georg II, was not changed, but only completed by a line acknowledging that Augustus had restored the chapel in 1728. Other figurative decorations were preserved as well: First, the two coats of arms, which represent Saxony as electoral state and Saxony-Wittenberg, were kept. Second, the two cartouches on the southern and northern wall of the chapel stayed unaltered; they portray Hebraic inscriptions based on Isaiah 6:3: "Holy, holy, holy, is the Lord of armies: all the earth is full of his glory!" This refers to Isaiah's epiphany. Third, the smaller scenes painted in grisaille technique were kept, including the Ten Commandments and the multiplication of bread, both on the northern wall, as well as Jesus in Gethsemane and the woman from Canaan, both on the opposite southern wall. Fourth, the illustrations on the doors to the sacristy and the musician's box were retained. The ones located at the pulpit represent faith in God: the baptism of Jesus in the Jordan River, the sacrifice of Elijah, Jesus and the Samaritan, Moses striking a rock for water, the temptation of Jesus, and the sacrifice of Noah. Those on the northern wall show the relationship of sovereigns with God: the fall of Jericho, the adoration of the Magi, David and the Ark

\footnotetext{
${ }^{29}$ Kretschmann, Schlosskapelle, 14; LfD, M28 C, ff. 16, 26 and 159.

${ }^{30}$ Meier, Sakralkunst, 60.

${ }^{31}$ Kathrin Ellwardt, Evangelischer Kirchenbau in Deutschland (Petersberg, 2008), 164.
} 
of the Covenant, the victory of the Israelites, David and Bathsheba, as well as David supported by God. These scenes were chosen because the king's private worship room was located behind that room. ${ }^{32}$ These Protestant decorations were not altered at all and seem to have been tolerable for Catholics.

It may be interesting to note that the sphere decorating Klengel's turret included a copy of the confession of Augsburg, which is based on Luther's 95 theses. Placing it in the highest point of the chapel tells us a lot about the religious values of the Saxon Protestants at the end of the seventeenth century. As it was not visible to the public, it might not have mattered for the Catholic rulers some decades later.

They mainly added portable religious items to adjust the chapel. Between 1728 and 1733, a statue of a little more than one metre in height was brought to Moritzburg: Christ on the column of flagellation, a truly baroque opus by Balthasar Permoser (1651-1732) that was completed in 1725 . He employed the unique red veined marble to create the optical illusion of real blood and thus enhance the sensation of suffering. This was indeed a typical characteristic for Catholic devotional pictures, especially those from Italy or the southern German states. An inventory of Moritzburg's court chapel, dating back to the year 1733, accounts for the liturgical vessels that had been donated prior to the death of Augustus: a gilded monstrance, a silver crucifix and six silver candlestick holders. ${ }^{33}$ An organ was already present before the refurbishing in Augustan times, so in that regard no changes were necessary.

Upon examination, it becomes clear that during the reign of Augustus the chapel did not undergo major modifications, although it had a typical Protestant iconography. Only under Frederick Augustus II more far-reaching adjustments were made.

\section{IV}

\section{THE COURT CHAPEL AT DRESDEN CASTLE}

Although the first Catholic mass was celebrated in the audience chamber in 1699 after Augustus' return from Poland, a true place for Catholic worship did not yet exist in Dresden. So soon after having

${ }^{32}$ Kretschmann, Schlosskapelle, 16-17.

33 Ibidem, 22. 
established Moritzburg, voices grew louder that this chapel was much too far away from the city itself to serve as the main place of Catholic worship for the Saxon court. ${ }^{34}$ Indeed, it took almost three hours to get there from Dresden by horse-drawn carriage.

After the old Renaissance residential palace suffered severe fire damages in 1701, Augustus' master builder Matthäus Daniel Pöppelmann (1662-1736) started planning a new baroque palace, which incorporated a Catholic court chapel. The project remained at the stage of pure planning, as the gigantic palace was much too vast to be realized.

In 1707 a private worship room was integrated into the old palace, but it was only a simple room for prayers. Thus, during the ten years between Augustus' conversion and the inauguration of a real chapel, the Catholic court members had to gather in the private chapel of the emperor's ambassador. In 1708 the former opera house was finally transformed into a Catholic court chapel which, not surprisingly, coincided with the temporary loss of the Polish crown ${ }^{35}$ and thus with the need for powerful support from the Catholic side. ${ }^{36}$

The chapel was dedicated to the Holy Trinity and a first service was held on 4 April 1708, Holy Thursday. Of course, this support of the Catholic faith within Saxony was immediately reported to the Pope along with a declaration of intent regarding the extent of services and personnel employed. ${ }^{37}$ Daily services were offered, and several priests, singers and others were appointed; the spiritual guidance came from the Jesuits. ${ }^{38}$ The chapel received the status of a royal chapel that was not overseen by a bishop, but directly by the Pope. ${ }^{39}$

The former opera house, despite not being a new building, was embellished according to the design of Johann Christoph von Naumann

${ }^{34}$ Saft, Neuaufbau, 16, citing the letters in question; Seifert, Niedergang und Wiederaufstieg, 141.

${ }^{35}$ Staszewski, 'Begründung und Fortsetzung', 45.

${ }^{36}$ Fitschen, 'Glaubenswechsel', 168; Jacek Staszewski, 'Die unterbrochene sächsisch-polnische Union nach dem Frieden von Altranstädt und vor Wiederkehr Augusts II. auf den polnischen Thron (1706-1709)', in Jürgen R. Wolf (ed.), 1707-2007 Altranstädter Konvention. Ein Meilenstein religiöser Toleranz in Europa (Halle, 2008), 51-7, here: 52. The Pope did not support the alternative King Leszczyński.

${ }^{37}$ Seifert, Niedergang und Wiederaufstieg, 143.

${ }^{38}$ Saft, Neuaufbau, 26-9.

${ }^{39}$ This status could only be kept until the death of the main Jesuit priest Carlo Maurio Vota in 1715; ibidem, 93. 


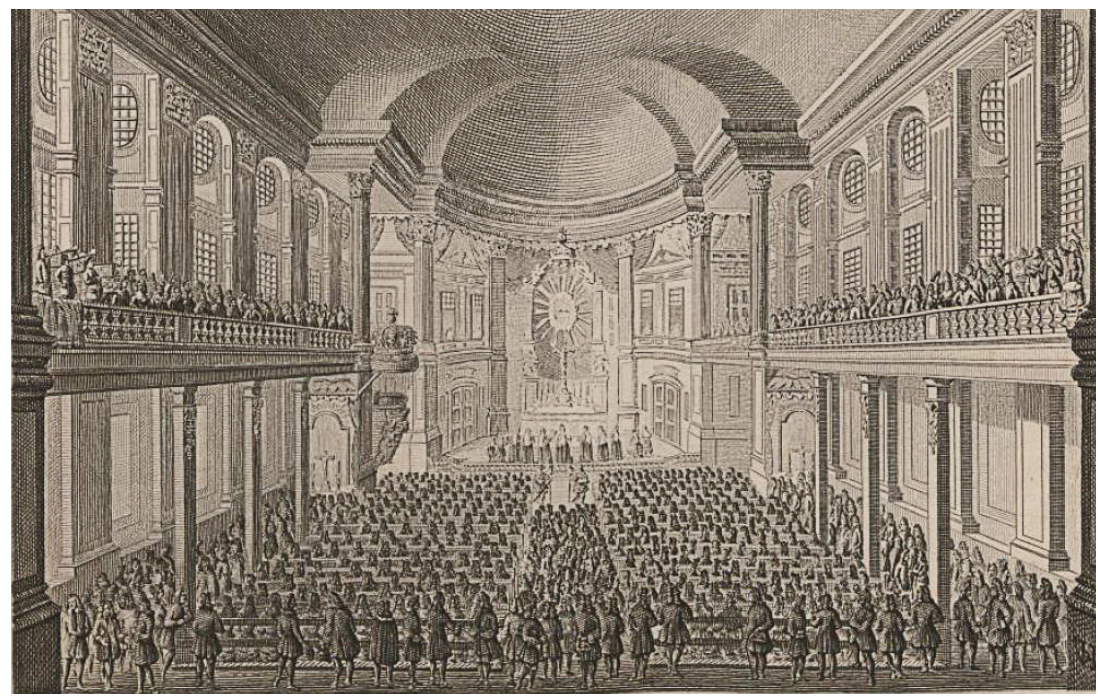

Fig. 2. Interior of the court chapel Dresden, Raymond Leplat, after 1719, SLUB/ Deutsche Fotothek.

(1664-1742) with much affords. ${ }^{40}$ Augustus' as architectural dilettante in the literal sense had also drawn plans for the chapel. ${ }^{41}$ The room had a longitudinal shape with an apse on its eastern side, a gallery for the choir, and an organ that was integrated in 1712 (fig. 2). ${ }^{42}$ Further galleries for the faithful extended into the hall, while the royal family had four boxes on each side of the altar. Augustus also asked for relics from Rome in order to consecrate the altar according to the Catholic rite. Additional altars were installed on the long wall, four in total.

The walls were decorated with red velvet, and the chapel was lit with candelabras, but the architecture was actually quite simple. The vessels came primarily from the Jesuit priests and some gifts from the Pope supported the furnishing of the chapel, while the robes had to be rented from the monastery Mariaschein (Bohosudov) in Bohemia for the first two years. ${ }^{43}$

${ }^{40}$ Joachim Menzhausen, 'Christliche Kunst am Hofe der sächsischen Könige von Polen', in Johann Lehner (ed.), Ecclesia triumphans Dresdensis (Wien, 1988), $1-7$, here: 4 .

${ }^{41}$ Dirk Syndram, Das Schloß zu Dresden (München, 2001), 59.

${ }^{42}$ Saft, Neuaufbau, 25.

${ }^{43}$ Ibidem, 23-5. 
It is interesting to look at the iconography: some sculptures embellished the chapel such as an annunciation group (1721), the Three Magi (1719) and a manger (1718). The pulpit was made by Balthasar Permoser (1681-1732) and showed the Polish crown on its canopy along with angels, which pointed to the Last Judgement, but also the evangelists that emphasized the importance of hearing the word. Furthermore, Permoser created the figure of the Apostle Peter and another suffering Christ at the column of flagellation.

The main altar was decorated with large angel statues, a work of Benjamin Thomae, who was of Protestant confession. The king's main court painter Louis de Silvestre (1675-1760) was responsible for the paintings of saints. Some paintings are known from the inventory of 1718, namely the Garden of Gethsemane, Moses and water from the rock, the bronze snake, the Salvator mundi, single images of Moses and John the Baptist, the crucifixion, the nativity and Holy Benno, bishop of Meissen. Not all paintings came from Silvestre: works of Lukas Cranach the Elder - including Christ and the adulterer - were added, and the ascension of Christ, done by Sebastiano Ricci, was hung at the entrance wall to complete the iconographic programme. ${ }^{44}$ Thus, also Protestant imagery was reused, ${ }^{45}$ and the scenes were reinterpreted in this context - even if the artists had intended another message when creating their œuvre.

A gradual distinction of imagery was made in particular concerning the altar: the first altarpiece was composed of two images of the Immaculate Conception and Holy Joseph, both name patrons of Maria Josepha. But in 1725 the Crown Princess asked Pellegrini to paint a new retable displaying the Trinity. She would become the main benefactor of Catholicism in Saxony, as evidenced in part by her support of the court chapel. Only much later the main altarpiece of Anton Raphael Mengs was added.

Interestingly, the multitude of figures and rich ornaments were perceived negatively by some Saxon Catholics, who were more familiar with the modest style of Protestant buildings. They also feared the mockery of Protestants who judged the Catholic expression of religion as a kind of idolatry. ${ }^{46}$ On the other hand, the Jesuits

${ }^{44}$ Meier, Sakralkunst, 95-7.

45 Ulrich Schöntube, Emporenbilderzyklen in der Mark Brandenburg, ein Beitrag zum lutherischen Bildprogramm des 16.-18. Jahrhunderts (Frankfurt, 2008), 550-61.

${ }^{46}$ Saft, Neuaufbau, 121; HStA, D. Loc. 2210, f. 33, the file was lost during the war. 
criticised the chosen images, especially the mostly non-figurative altar that concentrated on the symbols of the Trinity, for the lack of explicit imagery - even if Pellegrini's piece used Catholic traditions and took inspiration from the Chapel of Sacraments in St. Peter, Rome. ${ }^{47}$ Nevertheless, a gloriole that should represent the epiphany was a typology also common in Protestant altars. ${ }^{48}$ In 1725 wooden sculptures of St. Augustine and St. Ambrose, who had written treatises on the Holy Trinity, were added. Thus, after 1725 an own Catholic programme was steadily developed, although it was less specific in terms of confession than it might have been.

At this point it seems worth looking at the old court chapel. The old Protestant chapel was the highest-ranking chapel in all of Saxony as it belonged to the elector Augustus (1526-86). Having had a significant part in the Peace of Augsburg in $1555,{ }^{49}$ he gradually took over the role as the defender of Protestantism, which was also reflected by the layout and design of the chapel, finished in the same year.

The chapel was inspired by a palace chapel that had been consecrated by Luther himself, namely Torgau. Thus, it had a single nave and galleries arranged around the hall, a form that would become the model for court chapels throughout Saxony. Additional boxes for the organ surmounted the altar, which was fenced off from the main room. The ceiling still stood in the tradition of gothic vaulting and incorporated an iconography deriving from the Revelation of John: ${ }^{50}$ stars, angels, the Arma Christi, and snakes representing death and evil. The belief in salvation through the sacrifice of Christ was strong in the reformed church, but the second level of meaning of this iconography points to Michael and his fight against the dragon, thus representing the firm faith.

A restoration was undertaken during the reign of elector Johann Georg II (1613-80) through the master builder Wolf Caspar of Klengel. He installed a new organ, which was positioned in the newly rearranged eastern gallery. A large iconographic programme of apostles

${ }^{47}$ Meier, Sakralkunst, 108-12.

${ }^{48}$ Heinrich Magirius, 'Die Gloriole als Zeichen der Theophanie an evangelischen Barockaltären in Mitteldeutschland', in Hartmut Mai and Jens Bulisch (eds.), Kirchliche Kunst in Sachsen (Beucha, 2002), 85-110, here: 85.

49 Syndram, Schloss, 28.

${ }^{50}$ Heinrich Magirius, 'Schritte der Annäherung an ein fast verlorenes Baudenkmal, die evangelische Hofkapelle im Dresdner Residenzschloss', in Jens-Uwe Anwand (ed.), Das Schlingrippengewölbe der Schlosskapelle Dresden (Altenburg, 2013), 8-13, here: 8. 
or prophets was established and additional biblical verses explained the scenes shown. They correlated with the functions of the sacred space: the verses close to the confessionals referred to the confession, in the verses close to the pulpit, the word of God was the focus, and the altar space was embellished with verses praising God. ${ }^{51}$

The altar retable of the old chapel displayed Fides, Spes and Caritas, and in 1602 the figures of Moses and John the Baptist were added. Further original scenes were dedicated to Adam and Eve, the snake and the expulsion from the Garden of Eden, the adoration of the Magi, the crucifixion and the outpouring of the Spirit. The predella depicted the last supper. The typical altar in that time was composed of a predella with the last supper, followed by the crucifixion in the main section, topped by the resurrection or a gloriole. ${ }^{52}$ So overall it was not a strong Protestant iconography, with the exception of the emphasis on the word and the two additional figures that point in the same direction..$^{53}$

The chapel was included in the northern wing of the palace, but visible on the outside due to its magnificent portal, which led from the large courtyard into the chapel. ${ }^{54}$ The iconography of the portal, which is attributed to Giovanni Maria da Padua, was strictly Protestant showing Christ and the woman taken into adultery. The massive wooden door was most probably sculptured by Hans Walter II (1526-86) and presented scenes purely from Protestant ideas. Also, the monogram VDMIE, verbum Domini manet in aeternum, was inserted. It was the motto of elector Johann Frederick I (1503-54) in the Schmalkaldic League. He had cultivated a close relationship with Martin Luther.

The decline of this old Renaissance chapel began in 1725 when the entrance gate from inside the palace court was walled up and a new entrance was opened that only allowed the access from the outside. ${ }^{55}$ The altar was transferred to Torgau where it underwent some changes when the court chapel there began being used for

${ }^{51}$ Ibidem, 10.

52 Peter Poscharsky, 'Ikonographische Beobachtungen an lutherischen Altarretabeln in Sachsen bis zum Ende des Barock', in Mai and Bulisch (eds.), Kirchliche Kunst, 111-28, here: 113-17.

${ }^{53}$ Meier, Sakralkunst, 37-52.

${ }^{54}$ Heinrich Magirius, Die evangelische Schlosskapelle zu Dresden aus kunstgeschichtlicher Sicht (Altenburg, 2009), 10.

55 Ibidem, 20; Meier, Sakralkunst, 26-7. 
Catholic services in 1736. During the lifetime of Augustus II the Strong the Protestant services had already been relocated from the court chapel to the Sophienkirche, but in 1737, the chapel was demolished and secularized.

In conclusion, it is obvious that in Dresden a compromise was made between the Catholic wish to have an adequate court chapel and the Protestant demand not to do so too obviously. Augustus followed the path of least resistance: he reutilised an unused building, undertook some adjustments, and furnished it with items readily available. It was up to his daughter-in-law to make larger efforts in order to catholicise to chapel. It was also to her merit that a further private Catholic chapel was integrated into the princely palace at the Taschenberg when she and her newlywed Frederick Augustus moved into the palace in $1719 .{ }^{56}$

\section{$\mathrm{V}$ \\ THE PLEISSENBURG}

In Leipzig, the city of one of the largest trade fairs in the German territories and one of the main economic centres of Saxony, Augustus also dedicated a chapel or, more precisely, a small church building - to the Catholic confession.

The Catholic community had suggested renting an edifice, but the king favoured a building that belonged to his estate and should - hopefully - lead to fewer conflicts with the Protestants in the city. The main problem was that the services in the court chapels were somewhat private, but this newly dedicated church was open for public worship, a fact that stood contrary to the religious assurances made. The Catholics dedicated themselves to the furnishing of the chapel by planning three altars, supporting the payment of the construction and offering to pay for a priest. ${ }^{57}$ After the visit from the Pope's ambassador, Annibale Albani, the Roman Curia's wish to establish a place of worship in Leipzig was granted by Augustus - a smart move on his behalf to secure Rome on his side for regaining the Polish crown.

${ }^{56}$ Meier, Sakralkunst, 146.

${ }^{57}$ Birgit Mitzscherlich, 'Der Neubeginn des Katholizismus in Leipzig im 18. Jahrhundert', in Enno Bünz (ed.), Das religiöse Leipzig (Leipzig, 2013), 237-55, here: 240 . 
Of course, protests arose, but the decision had been made: ${ }^{58} \mathrm{~A}$ Jesuit named Heinrich Eggert was appointed as the leader of Leipzig's community and was assigned a room at the Pleissenburg. The old dining hall close to the tower was chosen to be refurbished and consecrated as a Catholic chapel..$^{59}$ Only seven weeks after the electoral decree, the first service took place on 3 June 1710, and regular services began a little later, on Pentecost.

The Pleissenburg was a castle built between 1552 and 1567. The chapel was placed in its northern courtyard (fig. 3) close to the tower of a bastion of fortification. ${ }^{60}$ It had three naves and was oriented towards the west. The dimensions were reconstructed with approximately 18 metres in length and 9 metres in width. ${ }^{61}$ The main staircase led from the southern side into the chapel, while another staircase on the south-western side provided an entrance to the court box. In the eastern corner, a spiral stairway led up to the galleries. The sanctuary had one main altar and two side altars placed in the naves on the western wall. The pulpit was positioned on the right side, the royal box on the left side, and after 1738, the singer's box was placed on the opposite wall. ${ }^{62}$ An organ was first purchased in 1720. Ephemeral structures are also known to have existed, for example, a manger and a Holy Sepulchre which were used for special occasions. ${ }^{63}$ The rites were supported by several vessels, for example a monstrance, which must have been donated by the Jesuits or wealthy members of the community.

By the end of the nineteenth century, only a few traces were left from the Augustan period. Some stucco ornaments that showed the Christogram "I. H. S." could be seen above the entryway; a contemporary description also mentions the Arma Christi above the court box as well as angel heads in a gloriole whose placement cannot be

${ }^{58}$ HStA, 10025, Loc. 4555, f. 103. Cf. Mitzscherlich, 'Neubeginn', 243. 247.

${ }^{59}$ Other sources trace it in the former royal stables; Mitzscherlich, 'Neubeginn',

${ }^{60}$ HStA, 12884, Karten und Risse, Schr. XXVI, F 95, no. 27, ca. 1770; Birgit Finger, 'Die Schlosskapelle von Pillnitz', Jahrbuch der Staatlichen Schlösser, Burgen und Gärten in Sachsen, vi (1998), 60-74, here: 61; Cornelius Gurlitt, Stadt Leipzig (Dresden, 1895), 303 and Pl. XXXVI.

${ }^{61}$ Mitzscherlich, 'Neubeginn', 247-8.

62 Saft, Neuaufbau, 136.

63 Ibidem, 138. 


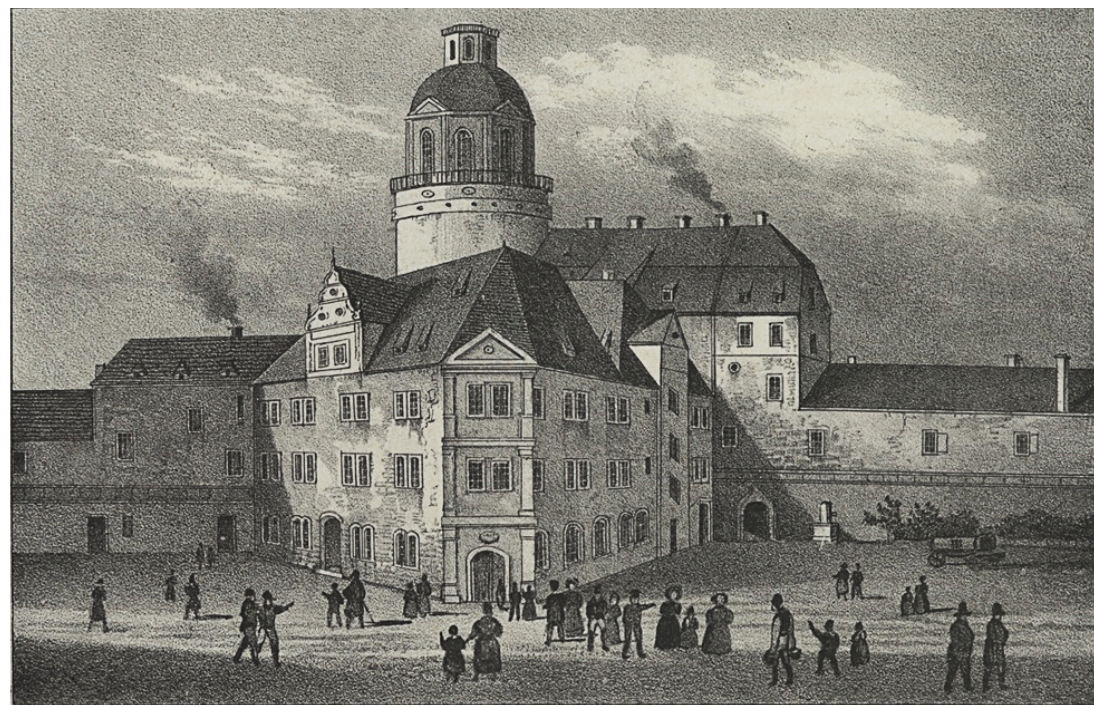

Fig. 3. The court of Pleißenburg castle with the Catholic chapel, Pietzsch, 1835, SLUB/Deutsche Fotothek.

traced anymore. ${ }^{64}$ By 1840 the chapel was dilapidated, and the Catholic community shifted to another church in the centre of Leipzig.

Although not much is known about the chapel in the Pleissenburg, it is clear that also here not much endeavour was developed from the elector's side. That said, the juridical situation in Leipzig was different from the one in Dresden, so in Leipzig Augustus could leave the initiative to the community and instead provide only an organizational support.

\section{VI \\ PILLNITZ CASTLE}

Another Catholic court chapel was planned for Pillnitz Castle, which was considered a maison de plaisance (pleasure palace). This impressive summer residence was located outside of Dresden. It was built between 1720 and 1723 according to the plans of Matthäus Daniel Pöppelmann and replaced an older manor at this site. The location was

${ }^{64}$ Gurlitt, Stadt Leipzig, 303. 
chosen due to its pleasant position close to the river Elbe with lush hills and vineyards behind the estate. During construction, the old church, which was erected in 1596, had to be demolished. ${ }^{65}$

Instead, a new structure was built, most likely following the plans of the architect Zacharias Longuelune (1669-1748). On first sight, it was not a religious building: the so-called Temple of Venus was a festive construction made out of wood. Due to its yellow plasterwork and grey roof it fit into the general ensemble very well. The layout was concentrated around an octagonal central room, from which two short corridors led to square rooms on the eastern and western side of the octagon (fig. 4). Each of those square annexes was connected to another square room by additional corridors positioned in a rectangular shape. The Catholic court chapel was integrated into the south-eastern room: from outside the building its function remained obscure, while only the inside furnishing revealed its religious use. Consecrated in June 1724 , only a few months after construction, it was dedicated to the Holy Trinity. ${ }^{66}$

During the summer months when the court stayed in Pillnitz, a daily service was given there, while the festive services were held in Dresden. The priests belonged to the court and travelled with the others to Pillnitz. Not much is known about the furnishings and iconographic design of the chapel, although it is said the altar painting originated from Lukas Cranach and that the ceiling was painted.

By 1777 the structure had decayed significantly, thus a restoration became necessary. This explains why today's chapel does not belong to the Augustan epoch. It was erected between 1823 and 1830 after a fire in the complex prompted the construction of additional buildings such as the New Palace. The chapel in the New Palace was also designed as a Catholic court chapel, thus keeping the continuity of the place.

Interestingly, Pillnitz Castle was not completely converted to Catholicism, as a new Protestant church was also included in the complex, due to lively protests against the demolition of the old church. So from 1723 to 1725, the new Protestant building was erected by Augustus

${ }^{65}$ A visual reconstruction of the late Gothic church can be found in Ferdinand Ludwig Zacharias, Sammlung historisch-topographisch- u. genealogischer Nachrichten über das Königl. Sächß. Cammerguth und Lust-Schloß Pillnitz (Dresden, 1826), ff. 40 and 42, Lit. Q resp. Lit. R (cf. SLUB, Mscr.Dresd.d.73).

${ }^{66}$ Finger, 'Schlosskapelle', 61-2; Zacharias, Sammlung, Pl. Lit. Y, Z and AA. 


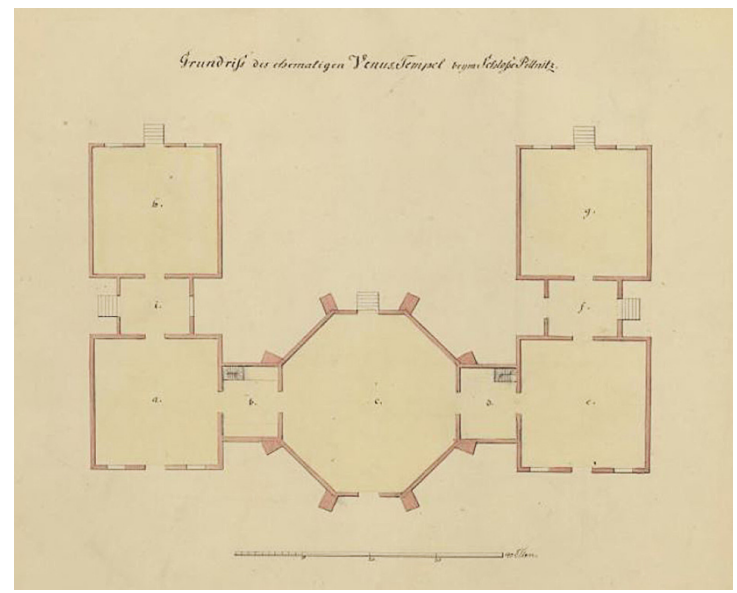

Fig. 4. The court chapel in Pillnitz in the Temple of Venus, Ferdinand Ludwig Zacharias, 1826, SLUB/ Deutsche Fotothek.

and the furnishings of the old church were reused. ${ }^{67}$ As a real church and not only a chapel, it received a ridge turret and an entrance portal sculpted by Johann Benjamin Thomae (1682-1751) with two coats of arms, one belonging to Poland, one belonging to Saxony, both surmounted by the king's crown. The longitudinal building is ten metres wide, twenty metres long and eight metres high. ${ }^{68}$ It was oriented to the east, with one entrance from the south and one from the west. Above the western entrance as well as three boxes, the organ found its place, while two galleries along the long sides of the church hold enough space for the court people joining the service. The altar, pulpit and the baptismal font originate from the old church and show a clear Lutheran iconography. The altar retable presents Christ among the apostles during the Easter meal, a scene enclosed by the figures of Peter and Paul, and crowned by a statue of Christ. ${ }^{69}$ Both with its text as well as its sculpture, the font refers to the baptism as written in the Gospel of Mark (Mk 16:16). ${ }^{70}$

${ }^{67}$ Dieter Fischer, 'Zur Geschichte und Restaurierung der Pillnitzer Weinbergkirche "Zum Heiligen Geist”, Dresdner Hefte, xxxiv (1993), 84-8.

${ }^{68}$ Zacharias, Sammlung, f. 48, Lit. U.

${ }^{69}$ Ibidem, f. 70, Lit. V, no. X.

${ }^{70}$ Ibidem, f. 72, Lit. Y, no. XI. 
To summarize the main characteristics of Pillnitz, it has to be said that Augustus did establish a Catholic chapel, although it was a modest one. The efforts he made for the new Protestant church were much greater. On the one hand, this may have to do with the number of Protestants at his court, but on the other hand, the elector would have had the means to support his new confession on a larger scale.

VII

THE JAPANESE PALACE

The Japanese Palace is situated on the northern side of the Elbe, in view from the residential palace on the opposite side the river. It was intended to be a real palace and not only a palais in the sense of a small building, a maison de plaisance, a pleasure villa. A court chapel should be incorporated from the beginning.

The Japanese Palace substituted a smaller edifice, which had been built between 1715 and 1717. Shortly after it was completed, Augustus bought the property from his minister Jacob Heinrich of Flemming (1667-1728) and developed affection for the palace and the place close to river. This led to extensive planning for the new construction of a larger palace: beginning in 1722 and especially after 1725, more than 300 plans were designed, until the final solution was found and construction could begin in 1729. Augustus never saw the palace of his dreams with his own eyes: he died in Warsaw on 1 February 1733. His death was also the reason why the palace was never finished. His son was not interested in the building and the ideas it represented; he preferred his palace Hubertusburg and also favoured the construction of a Catholic court church in the heart of Dresden.

Nine original plans for the chapel in the Japanese Palace from the building epoch still exist, but the chapel was never realised. The preserved plans date from 1729 to 1730 and show the development of the project. Indeed, it was not an easy architectural question as the space was quite limited due to the staircase in this wing that in the initial planning period should have been a double one. However, this idea had to be abandoned as the chapel's ground plan would have been too short, making it very small and badly proportioned for a chapel in a building of such importance. ${ }^{71}$ Thus, in the final plans

${ }^{71}$ HStA, 10006 OHMA, Cap. II, no. 15, ff. 1 and 25a. 


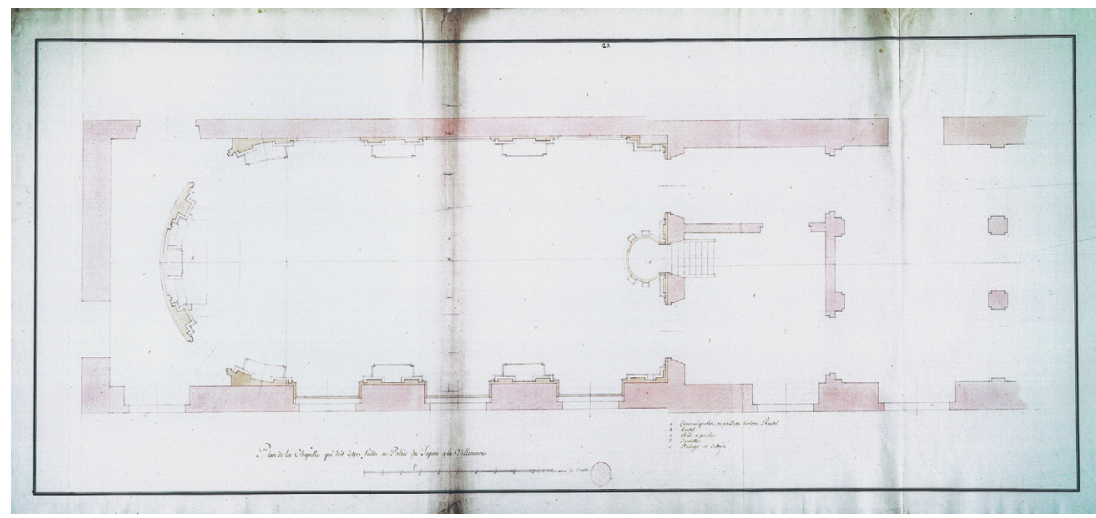

Fig. 5. Ground plan of the court chapel in the Japanese Palace, Zacharias Longuelune, 1730, HStA, 10006 OHMA, Cap. II, no. 15, f. 24c.

the chapel extended over four instead of three window axes, plus one additional axis as sacristy and access to the pulpit (fig. 5).

It is noteworthy how the chapel's layout was designed by the master builders Pöppelmann and Longuelune: the chapel was oriented toward the east and placed the altar - only one - into an apse that would have been built from wood. Interestingly, the pulpit, which was surmounted by the organ, would have been situated on the opposite side, next to the entrance that led from the staircase into the chapel. In terms of liturgical practice this was not such a good design as during services the faithful would have to turn around to see the altar and then turn back around to listen to the sermons. Nevertheless, this typology was known in Central Europe: in Charlottenburg this kind of chapel had recently been constructed between 1709 and 1712. Augustus himself had travelled to Berlin and Charlottenburg, for example in 1728, and was deeply impressed by the new architecture that Friedrich I of Prussia (1657-1713) had constructed. It is important to underline that this chapel was a Protestant one - but the splendour of the architecture and a possible superatio of his biggest rival made this model attractive.

From the archival material we know some of the planned iconographic characteristics of the court chapel in the Japanese Palace. The main feature would have been twelve life-sized statues of the apostles made from the prestigious Meissen porcelain. They were supposed to stand in front of the pillars between the arched windows, always grouped in pairs, Peter and Paul standing next to the altar (fig. 6). The 


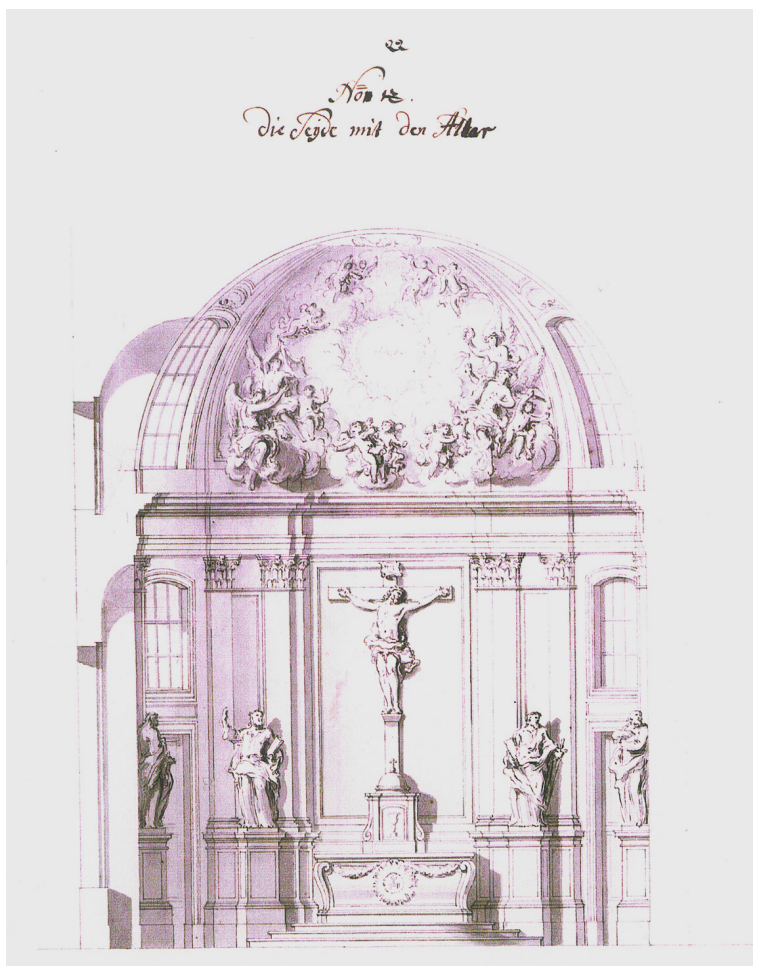

Fig. 6. Section through the court chapel in the Japanese Palace, Matthäus Daniel Pöppelmann, 1729, HStA, 10006 OHMA, Cap. II, no. 15, f. 25c.

earlier stage of planning was not explicit about the painted decorations as it only showed the faces of angels and indicated clouds as the basic scenery on the ceiling. The clerestory would have been painted with flaming hearts, a general sign of religious devotion. ${ }^{72}$ In the plans a tabernacle was displayed on the altar, which was supposed to be surmounted by a statue of the crucified Christ that would most probably also be made from porcelain. The apse of this first planning stage, created by Pöppelmann, displayed the Holy Spirit in a gloriole, surrounded by angels. ${ }^{73}$ In the cases discussed above, the Catholic altars in Saxony could not be distinguished from Protestant ones

${ }^{72}$ HStA, 10006 OHMA, Cap. II, no. 15, f. 24 b.

${ }^{73}$ HStA, 10006 OHMA, Cap. II, no. 15, f. 25c. 
by their form. As a relic had to be disposed in a Catholic altar, in Italy the typology of a sarcophagus altar had been developed. This remarkable form was planned for the Japanese palace.

The second stage of planning was undertaken by Longuelune, a Catholic French architect, who had been recruited from the Prussian court. He was influenced by classicist tendencies that led to a simpler architectural language without neglecting the representative character of the place. For the nave walls he kept Pöppelmann's idea of the apostles made from porcelain, but in the arches of the walls he introduced portraits that can be interpreted as biblical figures, bearded ones as well as young ones. ${ }^{74} \mathrm{He}$ also adopted the idea of flaming hearts on the clerestory wall and angels in the apse, but the main topic of the apse was changed to the ascension of Christ. For the entrance wall Longuelune presented two possibilities: The first displayed the Holy Spirit and the Vera Icon around the pulpit, flanked by supraportes that presented Jesus in front of Herod and possibly the entombment of Christ, and above them the organ like in the earlier planning. Longuelune's second plan used this space for further paintings of prophets or evangelists flanking the scene of the Sermon on the Mount (Mt 7:3-5) or the Sermon of John the Baptist (Mt 3:1-2) ${ }^{75}$ His concept for the altar space would have spared Peter and Paul by instead placing them in the nave, but he would have kept the crucifix above the altar.

Johann Joachim Kändler (1706-75), was the modeller who would have made the large saint figures out of the rare Meissen porcelain. The artist himself was even the son of the Lutheran priest. His figures for the Japanese Palace were never executed, but comparable statuettes were finished, of course at a much smaller scale, commissioned for high-level Catholics, including the cardinal Annibale Albani and the widow of the Austrian Emperor, Wilhelmine Amalia. Nevertheless, one porcelain statue of Saint Peter, an impressive two metres in height, was realised by Kändler. A whole chapel decorated with the twelve apostles would have shown the extraordinary potential and abilities of the Meissen manufactury - and thus the results of August's beneficial regency.

Thus, what we can see in the two planning stages for the most important Augustan palace, and respectively its chapel, is that almost

${ }^{74}$ HStA, 10006 OHMA, Cap. II, no. 15, ff. 24c-e.

${ }^{75}$ HStA, 10006 OHMA, Cap. II, no. 15, ff. 24a and 25b. 
none of the elements included were exclusively Catholic. Instead, the apostles and Christ were the focus of the planned programme. The suffering of Jesus might have had a slight tendency towards a Catholic understanding of faith, especially in the context of a more private place of worship, but those scenes were also perfectly acceptable for Protestants. There was no focus on Catholic saints or Maria as would be the case just one decade later for the newly built Catholic court church close to Dresden Castle.

\section{VIII \\ CONCLUSIONS}

Thus, it becomes clear that the idea of tolerance should be cautiously applied to the complex processes of interaction between the Protestant majority in Saxony and the Catholic minority, including the elector Augustus II the Strong himself. The Catholic coexistence with the Protestants was characterised by very prudent behaviour on the one hand, but a continuous progression of their own practice of religion on the other hand. This was a very pragmatic way of dealing with opportunities and challenges.

Dresden as a city attracted lots of artists from abroad, many of them Catholics. In the king's projects, artists of different confessions worked together to create the most magnificent pieces of art. Although this may give the impression of tolerance, the general political situation in Saxony was different from that, and only Augustus' cold attitude towards religion made it possible to combine both confessions within his court.

Nevertheless, the Jesuit clergy in Dresden had a strong influence on the elector, although it was not able to determine the construction activities. Some characteristics of design may have derived from their interference in the planning and construction process, but the clergy's influence was primarily limited to the donation of liturgical vessels. After the inauguration of Frederick Augustus II, they were able to exercise a major influence on the architecture.

After the death of Augustus, his son changed the religious politics within the realms of possibility. In contrast to his father, he was a very pious person, a characteristic that was strengthened by his strictly Catholic wife Maria Josepha (1699-1757). Thus, after he had reached some political stability, he was able to honour his faith to a greater extent. 
This self-confidence was visible in the Catholic Court Church, which is located next to the residential palace. Work on the church began in $1739,{ }^{76}$ and in order to disguise the construction that would surely cause extraordinary controversies, the building pit was even covered by tents. ${ }^{77} 78$ statues of saints were prominently placed on the roof of the cathedral, Franz Xaver among the most important ones. He was the personal patron saint of Maria Josepha and believed to have saved her from a fire. Other saints that were especially valued by the Jesuits also found their way into the church's iconographic programme, such as Ignatius of Loyola and Johann Nepomuk. ${ }^{78}$

Nonetheless, breaking openly with the religious agreements was not possible, so the church had to be equipped with a circumferential nave for housing the solemn processions that were not allowed in the public space of the city. The court church also had to do without bells that would have otherwise been a public sign of worship. Much time still had to pass until true tolerance of religions would exist in Saxony.

proofreading Francesca Hyatt

\section{SELECTED BIBLIOGRAPHY}

Christ Günther, 'Fürst, Dynastie, Territorium und Konfession', Saeculum, xxiv (1973), 367-87.

Finger Birgit, 'Die Schlosskapelle von Pillnitz', Jahrbuch der Staatlichen Schlösser, Burgen und Gärten in Sachsen, vi (1998), 60-74.

Fitschen Klaus, 'Der Glaubenswechsel Augusts des Starken im Spannungsfeld toleranz- und konfessionspolitischer Probleme', in Frank-Lothar Kroll and Hendrik Thoß (eds.), Zwei Staaten, eine Krone. Die polnisch-sächsische Union 1697-1763 (Berlin, 2016), 165-74.

Gierowski Józef A., 'Personal- oder Realunion?', in Johannes Kalisch and Józef A. Gierowski, Um die polnische Krone. Sachsen und Polen während des Nordischen Krieges 1700-1721 (Berlin, 1962), 254-91.

Gierowski Józef A., 'Die sächsisch-polnische Personalunion als Problem des Monarchen aus polnischer Sicht', in Rex Rexheuser (ed.), Die Personalunionen von Sachsen-Polen 1697-1763 und Hannover-England 1714-1837 (Wiesbaden, 2005), 121-52.

76 Saft, Neuaufbau, 111-19.

77 Freist, 'Religionssicherheiten', 46.

78 Saft, Neuaufbau, 43-4. 
Hartmann Hans-Günther, Moritzburg. Schloß und Umgebung in Geschichte und Gegenwart (Weimar, 1990).

Kretschmann Iris, Schlosskapelle Moritzburg (München, 1991).

Magirius Heinrich, Die evangelische Schlosskapelle zu Dresden aus kunstgeschichtlicher Sicht (Altenburg, 2009).

Meier Esther, Sakralkunst am Hof zu Dresden. Kontext als Prozess (Berlin, 2015).

Mitzscherlich Birgit, 'Der Neubeginn des Katholizismus in Leipzig im 18. Jahrhundert', in Enno Bünz (ed.), Das religiöse Leipzig (Leipzig, 2013), 237-55.

Saft Paul F., Der Neuaufbau der katholischen Kirche in Sachsen im 18. Jahrhundert (Leipzig, 1961).

Seifert Siegfried, Niedergang und Wiederaufstieg der katholischen Kirche in Sachsen (Leipzig, 1964).

Staszewski Jacek, 'Begründung und Fortsetzung der Personalunion Sachsen-Polen 1697 und 1733', in Rex Rexheuser (ed.), Die Personalunionen von Sachsen-Polen 1697-1763 und Hannover-England 1714-1837 (Wiesbaden, 2005), 37-50.

Staszewski Jacek, 'Die unterbrochene sächsisch-polnische Union nach dem Frieden von Altranstädt und vor Wiederkehr Augusts II. auf den polnischen Thron (1706-1709)', in Jürgen R. Wolf (ed.), 1707-2007 Altranstädter Konvention. Ein Meilenstein religiöser Toleranz in Europa (Halle, 2008), 51-7.

Tazbir Janusz, Geschichte der polnischen Toleranz (Warszawa, 1977).

Vötsch Jochen, Kursachsen, das Reich und der mitteldeutsche Raum zu Beginn des 18. Jahrhunderts (Frankfurt, 2003).

Kristina Friedrichs - art historical research; post-doctoral researcher at the Julius-Maximilians-Universität Würzburg, Institute of Art History;

e-mail: kristina.friedrichs@tu-dresden.de 